\title{
Erratum to: Resveratrol: A Multifunctional Compound Improving Endothelial Function
}

Editorial to: "Resveratrol Supplementation Gender Independently Improves Endothelial Reactivity and Suppresses Superoxide Production in Healthy Rats" by S. Soylemez et al.

\author{
Huige Li • Ulrich Förstermann
}

Published online: 18 February 2010

(C) Springer Science+Business Media, LLC 2010

Erratum to: Cardiovase Drugs Ther

DOI 10.1007/s10557-009-6209-0

The original version of this article unfortunately contained a mistake.

Line 7 of paragraph 3 under the heading Involvement of estrogen receptors and the question of gender differences should read "relaxation in endothelium-intact arteries from both male" instead of "relaxation in endothelium-denuded arteries from both male".

The online version of the original article can be found at http://dx.doi. org/10.1007/s10557-009-6209-0.

H. Li $(\bowtie) \cdot$ U. Förstermann

Department of Pharmacology, Johannes Gutenberg University,

Obere Zahlbacher Strasse 67,

55131 Mainz, Germany

e-mail: huigeli@uni-mainz.de 